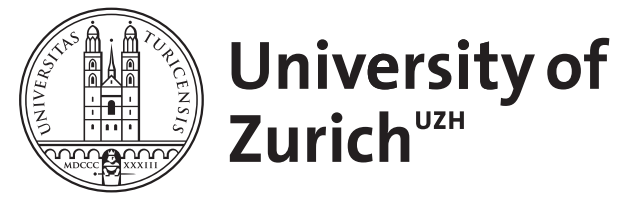
Archive

University of Zurich

University Library

Strickhofstrasse 39

CH-8057 Zurich

www.zora.uzh.ch

Year: 2017

\title{
Anne Clifford and her Bible
}

Bevan Zlatar, Antoinina

DOI: https://doi.org/10.1353/sel.2017.0007

Posted at the Zurich Open Repository and Archive, University of Zurich

ZORA URL: https://doi.org/10.5167/uzh-216207

Journal Article

Accepted Version

Originally published at:

Bevan Zlatar, Antoinina (2017). Anne Clifford and her Bible. Studies in English Literature, 1500-1900, 57(1):157-180.

DOI: https://doi.org/10.1353/sel.2017.0007 


\title{
Anne Clifford and Her Bible
}

\author{
ANTOININA BEVAN ZLATAR
}

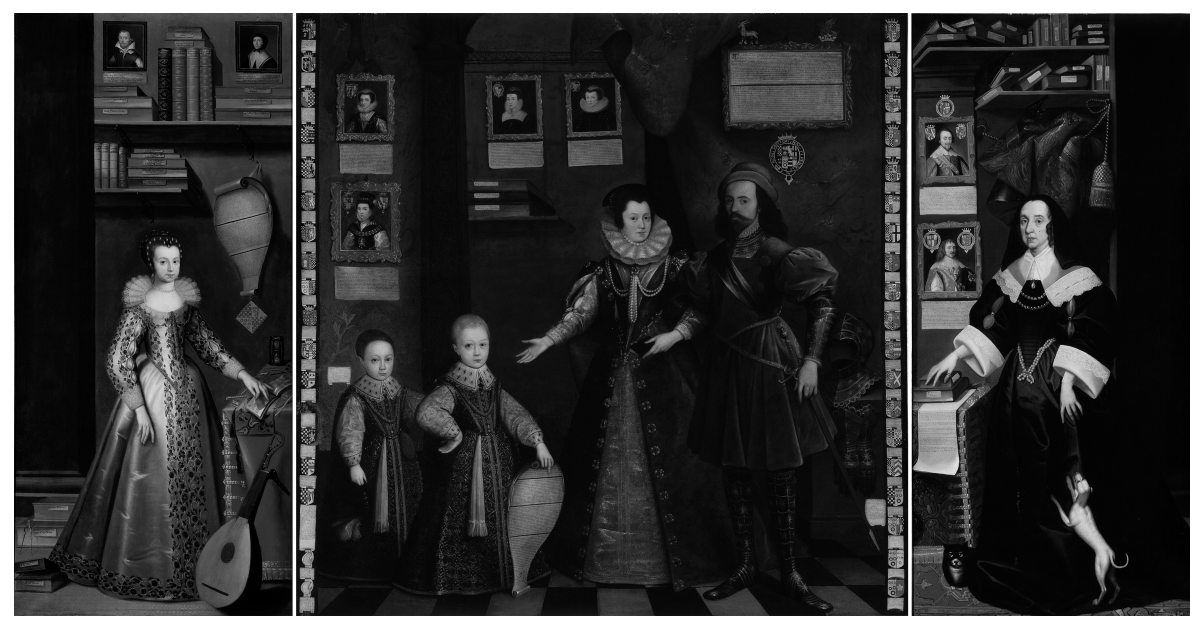

Figure 1. The Great Picture Triptych, 1646, oil on canvas, center panel 254 x $254 \mathrm{~cm}$, side panels 254 x $119.38 \mathrm{~cm}$. Commissioned by Lady Anne Clifford. Attributed to Jan van Belcamp. Reproduced by courtesy of Abbot Hall Art Gallery, Lakeland Arts Trust, Kendal, Cumbria UK.

The story of Anne Clifford (1590-1676), Countess of Pembroke, Dorset, and Montgomery, who fought and won a thirty-eight-year battle to reclaim almost 90,000 acres in Westmorland and Yorkshire that she deemed hers by right, is familiar to early modern scholarship. According to an entail imposed by Edward II, the Clifford lands and titles were to descend in direct line to heirs both male and female, but Anne's father, George Clifford, the third Earl

Antoinina Bevan Zlatar is the author of Reformation Fictions: Polemical Dialogues in Elizabethan England (2011). She is a Senior Teaching and Research Associate at Zurich University, currently preparing a monograph titled Making and Breaking Images in Milton's England. 
of Cumberland, having a daughter as his sole surviving heir, willed his lands to his brother and his male issue. From 1605 onward, Anne Clifford, with the help of her mother, publicly contested her father's will and, by refusing to relinquish her claim in return for a cash settlement, incurred the condemnation of her husband Richard Sackville, the Court, and King James I. Only when her cousin, Henry Clifford, died without male heirs in 1643 did the lands finally revert to her. ${ }^{1}$

Anne Clifford is herself the author of this tale and she tells it using a range of media: extensive writing in manuscript, the so-called Great Picture Triptych (1646) reproduced here, and inscriptions on the buildings she restored or founded in the north and on the monuments she erected. ${ }^{2}$ As is made evident in the Great Picture (Figure 1), which depicts some fifty volumes inscribed with legible titles, books played a significant part in Clifford's narrative. ${ }^{3}$ While scholarly attention has been lavished on the extent of Clifford's bookishness, much less has been said about her use of a particular Book, the Bible, the subject of this article. ${ }^{4}$ This lacuna can be explained by two biases in scholarship: the tendency to categorize Clifford's writings as secular rather than religious, and a certain reluctance to engage with the ways early modern men and women actually read the Bible, a wariness that is only now being rectified. ${ }^{5}$ The year 2011 , the 400 th anniversary of the King James Bible, witnessed numerous conferences addressing the place of the Bible in early modern culture. ${ }^{6}$ Since then a number of studies have furthered our thinking on how the Bible was read and appropriated; Kate Narveson's Bible Readers and Lay Writers in Early Modern England and Femke Molekamp's Women and the Bible in Early Modern England are of particular relevance here. ${ }^{7}$ This article proposes to extend this inquiry by focusing on how Clifford read the Bible and how this shaped her writings and visual memorials as a whole. This novel perspective will bring her remarkable consistency of purpose starkly to the fore. Moreover, it will demonstrate the futility of trying to divide the secular from the religious and the public from the private in the seventeenth century.

Clifford was a moderate Calvinist who believed in God's providential control of earthly affairs and the doctrine of predestination. ${ }^{8}$ She upheld Episcopal Church government and worshiped according to the Book of Common Prayer throughout her life. ${ }^{9} \mathrm{We}$ might call her a "Jacobethan," one whose religion had matured in the England of Elizabeth I and James I, a moderate whose circle of friends included Catholics and puritans. ${ }^{10}$ While critical of 
individual Stuart monarchs and their Courts, Clifford remained a lifelong Royalist. She was intimate with James I's Queen Anne and later with Charles I's Queen Henrietta Maria; after the Restoration she celebrated the anniversary of Charles II's accession in great style. ${ }^{11}$

During the Civil Wars, the main Clifford seats of Skipton and Appleby Castles fell to the Parliamentarians in 1646. Skipton was partially demolished after a Royalist uprising in 1648, while Appleby lost its roof. Further damage to her property was prevented by the intervention of her second husband, Philip Herbert, fourth Earl of Pembroke, who, erstwhile Lord Chamberlain to Charles I, had become a prominent Parliamentarian in $1641 .{ }^{12}$ It was not until 1649 that Clifford returned to the north and set about the extensive restoration of her properties. She rebuilt her castles and their attendant churches and chapels. She founded almshouses and, through acts of mercy and concern for the religious education of her households, made piety a distinctive feature of her governance in Westmorland and Craven. ${ }^{13}$ "Religious" was an epithet she used on the inscription she devised for her coffin, and the figure of "Religion" stands on the reverse side of the silver commemorative medals she gave to her officers and almswomen. ${ }^{14}$

It is in the "diaries" of 1616-19 that we learn most about Clifford's Bible and how she read, internalized, and began to apply it to herself in her writing. But it is not until the Great Picture, her autobiographical tract known as "A Summary of the Records and a True Memorial of the Life of Me the Lady Anne Clifford" (1652), and the annual summaries of 1650-75 that she systematically deploys the Bible to shape her narrative. ${ }^{15}$ She uses references to Isaiah, Jeremiah, and Job alongside references to the psalms to express and sanction emotions and to delineate and justify acts of resistance while remaining a model of Stoicism and maintaining the decorum of her chosen genre-not life writing so much as divinely sanctioned family history. The biblical book Clifford most identified with was clearly the Book of Psalms. By appropriating David's words, she had license to express fear and helplessness, confidence in the justice of her cause, anger, demands for vengeance, and, finally, gratitude for God's protection. ${ }^{16}$ She could reference Psalm 37:22 ("Such as are blessed of God shall possess the land: and they, that are cursed of him, shall be rooted out") so as to assert quietly but firmly her belief that she had reclaimed the land of her ancestors through the providence of God, and that this was proof of God's special favor. ${ }^{17}$ 
Deploying the psalms to assert one's own blamelessness and to ask God to punish or to destroy one's enemies should come as no surprise. As Alec Ryrie has reminded us, the psalms were very much Old Testament texts in their resolutely this-worldly focus and in their punitive justice. ${ }^{18}$ Preeminently applicable in times of crisis, and especially useful when confronting spiritual enemies, the psalms became particularly attractive to Protestants who tended to understand their lives in terms of spiritual warfare. As for interpreting one's worldly successes and the demise of one's opponents as proof of God's special favor, this should not strike us as presumptuous or spiritually defective. Blair Worden and Alexandra Walsham have shown just how pervasive such providentialism was in early modern England. ${ }^{19}$ We find models of piety acting very similarly. "And further I must not let slip out of my mind what God hath done for me in my own particular inheritance whereunto I was lawfully born," writes Lady Grace Mildmay, remembering how her sister and brother-in-law had persuaded her father to change his will to Mildmay's great disadvantage but "God the Lord of life and Father of our fathers prevented and frustrated their purposes" by making her father die before his time and by humbling her sister's heart with troubles so that she eventually gave Mildmay her due portion of land. ${ }^{20}$

In what follows, I suggest we take seriously Clifford's belief in divine intervention in the restoration of her ancestral lands and properties. Her conviction is best understood in the context of a particular discourse on lineage premised on the idea that the longevity of a family line-the fragile conjunction of blood and land down through the generations - was ultimately dependent on God's blessing. Felicity Heal and Clive Holmes have charted the survival of this medieval conception of lineage from the 1560 s to 1680 , a time when the nobility and gentry came under pressure from unprecedented social mobility and the genetic lottery saw a quarter of landed families die out in the male line in the course of a generation. ${ }^{21}$ This older conceptualization rubbed shoulders with newer, more horizontal understandings of gentility based on humanist education and civil behavior, on Protestant concepts of godliness and grace, or, more pragmatically, on wealth. Thus, Sir Edward Dering, whose antiquarian researches established an inventive pre-Conquest line of descent for himself, could write of the doctrine of grace as "a tearme beyond all ascentes of climing degrees, to be the Sonnes of God," while asserting that "descent of bloud even among men and abstracted from this high advance is a blessing." 22 
Moreover, in the seventeenth century this preoccupation with lineage produced a rich material culture of dynasty ranging from giant pedigree rolls, to elaborate funeral monuments, to declamatory heraldic designs on the façades of buildings and items of furniture inside both churches and the home. Time and again this language of dynasty fused the secular and the religious. ${ }^{23}$ For example, the inscription found on an ornamental fireplace commissioned by Clifford in 1664 to commemorate the wedding of her grandson Nicholas Tufton, Earl of Thanet, and Henry Clifford's granddaughter, Elizabeth Boyle, reads "GODS PROVIDENCE IS MINE INHERITANCE," the motto that Elizabeth's paternal grandfather, Richard Boyle, had adopted when he became the Earl of Cork. ${ }^{24}$ This marriage effectively healed the breach between Clifford's and her cousin Henry's lines. ${ }^{25}$

\section{READING AND HEARING THE BIBLE AND APPLYING IT TO ONESELF}

An entry in Clifford's diary from February 1617 reads: "Upon the $24^{\text {th }}, 26^{\text {th }}, 27^{\text {th }}$, I spent my time in working [i.e., needlework] and hearing $\mathrm{M}^{\mathrm{r}}$ Ran read the Bible and walking abroad" (p. 121). Mr. Ran was one of her husband Richard Sackville's chaplains. On 8 March she notes "I made an end of Exodus with $\mathrm{M}^{\mathrm{r}}$ Ran," and on 13 March "I made an end of Leviticus with $\mathrm{M}^{\mathrm{r}}$ Ran" (p. 123). By 27 March she has come to the end of Deuteronomy. But on 27 March Sackville reclaims his chaplain for his own uses. She notes "My Lord found me reading with $\mathrm{M}^{\mathrm{r}}$ Ran and told me that it would hinder his study very much so as I must leave off reading the Old Testament until I can get somebody to read it with me" (p. 125).

At one level these entries function as a reading diary, reminding Clifford what she was reading when and where, how long it took, and invariably which member of her household had read aloud to her. ${ }^{26}$ Such aural reading was common among aristocratic women, and in this case it frees Clifford's hands for her stitch work. ${ }^{27}$ Indeed, the Bible was one among many books she records having had read to her between 1616 and 1619. She hears "the History of the Netherlands" and "Montaigne's Essays" in the autumn of 1616 at Brougham Castle (p. 99) ${ }^{28}$ In January 1617 in her closet at Knole she has " $\mathrm{M}^{\mathrm{r}}$ Sandys his Book read to me about the Government of the Turks," and in the same month Sackville's cousin Moll Neville reads to her from Spenser's "Fairy Queen," and the following August from Philip Sidney's "Arcadia" 
(pp. 109-11, 117, and 145). In April 1617 she reads "the Turkish History and Chaucer" in her husband's closet, this last detail indicative of a marital rapprochement (p. 131). In 1619 it took her servant Wat Conniston a month to read her " $\mathrm{S}$ "Austin [Augustine] of the City of God" (pp. 159 and 162). February and March 1619 were spent in voracious reading: in addition to Augustine, Clifford listens to "the King's book upon the Lord's Prayer," a book "in the praise of a Solitary Life" that had belonged to her mother, and Thomas Sorocold's "Supplication of the Saints," a gift from Sackville (pp. 158 and 163). ${ }^{29}$ And all the while she is busy with another book. On 20 March she notes "I made an end of reading the Bible over which was my Lady my mother's. I began to read it the $1^{\text {st }}$ of February so as I read all over the whole Bible in less than two months" (p. 163).

This catalog of books contributes to one of the great pleasures of Clifford's early writing: its evocation of the material world of the seventeenth century wherein the book as object exists alongside other objects, such as a taffeta gown, her daughter's baby teeth, or the rosemary cakes she makes. Such materiality is of course compounded by the visual representation of some of the books in the Great Picture, and by the extant copies of her books in record offices and libraries. But I suggest that in the case of the Bible this materiality is weightier still. On 16 March 1617, having perhaps commenced Numbers with Mr. Ran, she writes, "This day I spent walking in the Park with Judith and carrying my Bible with me thinking on my present fortunes and what troubles I have passed through" (p. 123). By 1617 there were a number of Bible formats on offer, and the one she carries out into the Park was presumably appropriately sized, a handy octavo or perhaps a duodecimo. ${ }^{30}$ Carrying a Bible about was not unusual, yet here Clifford's book retains what David Cressy has described as "totemic" properties. ${ }^{31}$ She carries it in her hand or in a pocket, perhaps clasped to her breast, and even closed it seems to provide solace at this particularly troubled point in her life.

Her troubles, movingly evoked here and alluded to consistently in her later writings, are provoked by the pressures she faces at home and abroad to sign away the titles and lands she considered rightfully hers. In February 1616 in the gallery at Dorset House, Sackville's London residence, she records that all her male relatives had assembled and that the Archbishop of Canterbury, George Abbot, took her aside and "persuaded me both by divine and human means" to relinquish her claim to her patrimony in return for a cash settlement (p. 71). She refused. Sackville, badly 
in need of money, seems to have threatened her with separation, and after further refusals to sign, he dismisses her retinue, threatens her with eviction from Knole, and in early May takes away her only child. She records going "to the standing in the garden early in the morning with my prayer book" and weeping "bitterly" (pp. 77 and 79). ${ }^{32}$ On 12 May she famously contrasts her life at Knole with Sackville's up in London: "All this time my Lord was at London where he had infinite and great resort coming to him. He went much abroad to cocking, to bowling alleys, to plays and horse races and was commended by all the world. I stayed in the country having many times a sorrowful and heavy heart, and being condemned by most folks because I would not consent to the agreements, so as I may truly say I am like an owl in the desert" (p. 83). This last clause is an unacknowledged quotation from Psalm 102, one of the seven penitential psalms and among those read at Prayer Book services on Ash Wednesdays. ${ }^{33}$ It allows her to appropriate for herself the Psalmist's terrible evocation of a withering, all-consuming loneliness, his sense of being cast out of society, shunned by his enemies:

Hear my prayer, O Lord: and let my crying come unto thee. Hide not thy face from me in the time of my trouble: incline thine ear unto me when I call; O hear me, and that right soon. For my dayes are consumed away like smoke: and my bones are burnt up as it were a fire-brand. My heart is smitten down, and withered like grass: so that I forget to eat my bread. For the voice of my groaning: my bones will scarce cleave to my flesh. I am become like a pelican in the wilderness: and like an owl that is in the desert. I have watched, and am even as it were a sparrow: that sitteth alone upon the house-top. Mine enemies revile me all the day long: and they, that are mad upon me, are sworn together against me.

(Ps. 102:1-8, p. 562)

In late May Clifford loses her mother, her best ally in the inheritance battle. By January 1617 the king has taken charge of the proceedings and on 21 January Clifford records being summoned into James's chamber along with Sackville and a battalion of male relatives, ultimately putting the king "into a great chaff" by refusing to sign away her patrimony in return for a cash settlement (p. 113). Clifford explains her remarkable resolve: "This day I may say I was led miraculously by God's providence" (p. 
115). Sackville is now in with the king but "clean out" with Clifford, and it is then that she documents her careful reading of the Pentateuch with Mr. Ran (p. 117). In this context, it is hard not to interpret her reading of the history of the chosen people, their trials and survival through God's intervention, in more subjective and combative terms. Similarly, Sackville's seemingly casual move to reclaim his chaplain for his own study becomes an act of retributive disempowerment. What at first seems a detail of private reading here takes on more political overtones. ${ }^{34}$

\section{HABITS OF SCRIPTURAL READING}

Clifford's systematic and repeated reading of the Bible was not exceptional. The literate of both sexes and of all classes and religious confessions read the Bible systematically and selectively, and they did so repeatedly. They knew parts of the Bible by heart-Paul's Epistles as well as all of Psalms. ${ }^{35}$ This conformed to the prescriptions proffered, for example, by the puritan preacher John Downame in A Guide to Godlynesse (1622). ${ }^{36}$ Clifford may well have known this work; she certainly knew Downame's The Christian Warfare (1604), one of the volumes depicted in the youthful left-hand panel of the Great Picture. Downame allows that some biblical books may excel others in "setting forth the maine points of our saluation more fully and plainely," and he ranks the prophets above the books of Moses, and gives Psalms pride of place. ${ }^{37}$ Ultimately, the Old Testament is superseded by the New since "the Old Testament is the New hid and shadowed, the New Testament is the Old vnfolded and reuealed." 38 Some commentators favored reading the Bible out of sequence, but Downame advises his reader "to begin at the beginning, and so to proceed till we come to the end." 39 This, he explains, "will be a notible helpe both for the vnderstanding of the matter, and the History of the Bible, when as we obserue the coherence, and how one thing dependeth vpon another." ${ }^{40} \mathrm{He}$ also recommends repeated reading as well as memorizing and internalizing; he claimed to have read the scriptures "seriously twice or thrice." 11

In 1617, aged twenty-seven, Clifford read her Bible in order, beginning at the beginning and working her way steadily through to Deuteronomy. In 1619 she read the whole Bible in two months. In seeking out Mr. Ran, the chaplain, to read the Old Testament with her, she was choosing an expert in "open[ing]" the scriptures, again something regularly prescribed in the advice literature. ${ }^{42}$ In addition to reading the scriptures, Downame recommends 
Protestant commentators, notably John Calvin, William Perkins, Richard Rogers, Arthur Dent, and Joseph Hall. Judging by the books she denotes in the Knole diary and by those she includes in the triptych, Clifford also read biblical histories and a range of contemporary interpreters that reflect not only her moderate Calvinism but also her family loyalties and connections. On 14 December 1619, Conniston began to read her "the book of Josephus ... of the Antiquities of the Jews" (p. 189). On the youthful left-hand panel of the Great Picture, standing on the uppermost shelf, we see Augustine's City of God, which Conniston had read to her in early 1619, Eusebius's History of the Church, and Joseph Hall's Workes. ${ }^{43}$ Hall was chaplain to Prince Henry and a moderate Calvinist admired at the Jacobean Court for his preaching and Senecan prose. ${ }^{44}$ On the "older" right-hand wing on the upper shelf, we find George Sandys's Paraphrase upon the Psalms of David and William Austin's Meditations. George Sandys was George Clifford's godson, and William Austin, who shared Lancelot Andrewes's sacramental theology, was a friend of Ben Jonson. ${ }^{45}$ Jonson's Workes are to be found on the same shelf as Austin's volume, the former a memento of Clifford's appearances in various Court masques in 1608 and 1609. Conspicuous by their absence among her religious books are Calvin, Perkins, and Richard Hooker.

Private reading and hearing of the Bible was of course supplemented by more public hearing and reading during Prayer Book services. The Book of Common Prayer contained tables stipulating which psalms and which passages from both Testaments were to be read each day; theoretically, those attending Morning and Evening Prayer daily would hear all the psalms once a month, most of the Old Testament once a year, and the New Testament (excluding Revelation) three times a year. ${ }^{46}$ Clifford's attachment to the Book of Common Prayer was lifelong. During the Cromwellian ban she continued to follow its rubric in the privacy of her castles. ${ }^{47}$ In her final daybook, she records the many occasions when the parson came to the chamber where she was confined to say Common Prayers and to read the chapter and psalms for the day. ${ }^{48}$ And then there were sermons. We know that Clifford heard Mr. Ran preach in the chapel at Knole House on Sundays, but when preachers of note came to the church at nearby Sevenoaks, she records going to listen to their sermons. This was the case on 27 July 1617 when John Donne graced the pulpit (p. 143). Unfortunately, she says nothing of the subject of his sermon. In London she records hearing a sermon at St. Bride's on 
23 June 1616, one at Court on 19 January 1617, and another in Sackville's chapel at Dorset House on 25 December 1617, but she does not name the preachers (pp. 91, 111, and 151). She would presumably have heard the stars of the day: Andrewes, Abbot, and John King. Later, during her time at Court in the 1630s, she would have encountered William Laud. Yet of these only Donne's and King's sermons feature in the Great Picture. ${ }^{49}$ Clifford seems to have known King well enough to write to him in her distress in 1617 (p. 137). King was a friend of Donne and held in high regard by Queen Anne. ${ }^{50}$

Clifford appears to have had access to a number of Bibles at Knole, and we can speculate that these were different translations. She records that the Bible she was reading in 1619 was "my Lady my mother's" (p. 163); its having belonged to her "blessed" mother would have increased its import. ${ }^{51}$ This was most likely the Geneva version. ${ }^{52}$ Was the Bible Clifford read with Mr. Ran in early 1617 the King James Bible, a presentation copy even, given to her by Archbishop Abbot or by Dr. John Layfield, both mentioned in the diary and both part of the King James translation project? ${ }^{53}$ As for the scriptural lessons read at Prayer services, the texts were taken from the Great Bible of 1539 right up until the revised Book of Common Prayer of 1662, when, with the exception of Myles Coverdale's Psalms, the King James translation was preferred. ${ }^{54}$

Immersion in biblical culture-repeated reading, hearing, and explications of Holy Writ - would have favored internalization and Clifford certainly knew parts of her Bible by heart. She quotes Psalm 102 in the Knole diary; her "like an owl in the desert" is closer to the wording of the Great Bible than to that of the Geneva or the King James versions. In "The Life of Me," she quotes rather than denotes biblical passages on two occasions. After an unabashed eulogy of her own physique, she comments, "But now time and age hath long since ended those beauties, which are to be compared to the grass of the field. Isaiah 40:6, 7, 8; 1 Peter 1:24" (p. 220). ${ }^{55}$ Later, when documenting her father's prodigious pedigree, she notes that "in all which long time those lands descended still from father to son, except twice, that they descended to the younger brother, the elder dying without issue ... 'for those were ancient times,' as I Chronicles 4:22" (p. 222) ${ }^{56}$ In both instances she seems to be quoting from memory, her wording an amalgam of Geneva and King James.

Careful study of her diaries and letters reveals that Clifford read, internalized, quoted, and adapted other texts in her library too. Yet the internalizing evidenced by such quotation is of a dif- 
ferent order when the book is the Bible. When she quotes Sidney's Arcadia or Spenser's Faerie Queene, Clifford's quotations are unacknowledged, but when she quotes Holy Writ, the borrowed words are proclaimed by means of reference to biblical book, chapter, and verse. This is God's Word and she is deploying it as proof of his hand in her resolution to stand against and ultimately triumph over a series of male figures of authority.

\section{SCRIPTURE AS PROOF}

The use of scripture to demonstrate God's providential hand in Clifford's history is nowhere more evident than in two pendant pieces: the Great Picture, which she commissioned circa 1646, and "The Life of Me." These works use different media to tell the same story-that of Clifford's conception, birth, and survival; her disinheritance in 1605; and, thirty-eight years later, the restitution of her lands-and they make plain that all occurred in accordance with God's plan.

"The Life of Me" appears in the last of the three Great Books of Record, the manuscript volumes compiled at Clifford's mother's instigation and completed by Clifford so as to provide her lawyers with incontrovertible documentary evidence of her right to the contested Clifford titles. Embellished with genealogies and supplemented by Clifford's own summaries of the lives of each of her titled ancestors, the Great Books constitute a scholarly and remarkably complete history of her family. ${ }^{57}$ That Clifford has applied the Word of God to herself is apparent from the unmistakably biblical "begotten" of the opening line: "I was, through the merciful providence of God, begotten by my valiant father, and conceived with child by my worthy mother, the first day of May in 1589 in the Lord Wharton's house in Channell Row in Westminster, hard by the river Thames, as Psalms 139" (p. 218). Thereafter, chains of references-invariably from the Old Testament-conclude each phase of her life. She collates passages taken from different parts of individual books of the Bible or across books. This practice, known as "conferring place with place," advertised the coherence of the Bible as a text, and suggested that dark places could be illuminated by other biblical passages and that disparate biblical passages could corroborate a particular doctrine or conviction. ${ }^{58}$ Biblical chains of this kind fill the margins of the Geneva Bible, and printed concordances were readily available. It was a practice that transcended class and sex. In "The Life of Me" we find references to Isaiah and Job alongside references to Psalms, but the book cited most often is Psalms. 
"But happy births are many times attended on by cross fortunes in this world, which nevertheless I overcame by the divine mercy of almighty God, Psalms 121" (p. 220). Clifford evokes the whole of Psalm 121 here, proclaiming God as her helper, keeper, and preserver. A few pages later in an often-quoted passage on her marital difficulties, she concludes, "And by a happy genius I overcame all those troubles, Psalms 62, the prayers of my blessed mother helping me therein. Isaiah 5:16; Isaiah 26:20; Psalms 57; Psalms 43; Psalms 71; Isaiah 30:9-10" (pp. 225-6). These psalms are much less celebrations of God's sleepless care than expressions of the Psalmist's anguish and doubt in the face of his enemies. "Be merciful unto me, O God, be merciful unto me, for my soul trusteth in thee: and under the shadow of thy wings shall be my refuge, until this tyranny be over-past," he implores at the start of Psalm 57 (Ps. 57:1, p. 517). "[M]y soul is among lions. And I lie even among the children of men, that are set on fire: whose teeth are spears and arrows, and their tongue a sharp sword" (Ps. 57:4-5, p. 517). Psalm 71 is more anguished still: "I am become as it were a monster unto many ... For mine enemies speak against me, and they, that lay wait for my soul, take their counsel together, saying: God hath forsaken him, persecute him and take him, for there is none to deliver him. Go not far from me, O God: my God, haste thee to help me," he begs (Ps. 71:9-10, p. 530). Then, in the next verse he demands vengeance: "Let them be confounded and perish, that are against my soul: let them be covered with shame and dishonour that seek to do me evil" (Ps. 71:11, p. 530). Indeed, when Clifford comes to discuss her inheritance battle, a reference to Psalm 40:15-7 is directed at specified men-at her husband Sackville, her uncle Francis Clifford, her cousin Henry, and also at King James himself (p. 227): "Let them be ashamed and confounded together, that seek after my soul to destroy it: let them be driven backward, and put to rebuke, that wish me evil" (Ps. 40:17, pp. 502-3). The harshest critique is reserved for her brother-in-law, Sir Edward Sackville, whose "malicious hatred" she claims to have endured for fortythree years: "but I, whose destiny was guided by a merciful and divine providence, escaped the subtlety of all his practices, and the evils which he plotted against me" (p. 230). She ends with a volley of psalms invoking divine vengeance on the wicked: "Psalms 35; Psalms 37; Psalms 140” (p. 230).

In 1617 Clifford used Psalm 102 to give voice to her loneliness at Knole, cast out of London society for refusing to obey father, husband, and king. In "The Life of Me," now that she is mistress 
of her vast northern territories, she evokes David's trials, fervent prayers, and redemption so as to delineate a spectrum of emotions. Clifford knew that silence and obedience were prescribed for her sex and that anger and vengeance were not seemly. In a letter of 1615, her mother advises her how to deal strategically with her husband in the inheritance battle: "Lay all on me and neither cross him in words but keep your resolutions with silence and what gentle persuasion you can, but alter not from your wise course." ${ }^{59}$ We see Clifford putting this advice into practice in the diary of 1616-19, cleverly using her mother as an excuse to win time and endeavoring "to take all patiently casting all my care upon God" (p. 135). Using David as an exemplum allows Clifford to authorize her circumvention of the dictates enjoining daughters, wives, and subjects to silence and obedience. Women of all classes and shades of Protestantism had done likewise. Margaret P. Hannay sees a similar strategic use of Psalms at work in the paraphrases of Anne Askew and Katherine Parr. ${ }^{60}$ Molekamp couples Clifford's providential use of the Bible in "The Life of Me" with that of Agnes Beaumont, the daughter of a yeoman and a zealous Nonconformist. ${ }^{61}$ In Salve Deus Rex Judaeorum (1611), Aemilia Lanyer numbers Clifford and her mother Margaret Russell among her dedicatees, and uses Psalms and Revelation to prophesy the destruction of Margaret's enemies and her subsequent glorification. Molekamp suggests that the prophetic use of biblical books, nascent in Lanyer and Clifford, would develop into full-blown apocalyptic fervor in the writing of sectarian prophetesses on the eve of the Civil Wars. ${ }^{62}$

If the use of David allows Clifford to express vehement emotions without defying the norms prescribed for her sex, then it also allows her to embed her own personal story in biblical history, and align her struggle and redemption with that of David and ultimately Christ. As noted earlier, in evoking Psalm 37:22-"Such as are blessed of God shall possess the land: and they, that are cursed of him, shall be rooted out" (p. 498)—Clifford suggests that she has inherited the land through the providence of God. The fact that the lands have reverted to her is proof of God's special favor and sustains her hope that she is one of the elect. This providential narrative of the restoration of worldly goods-Clifford's ancestral lands-through divine intervention should be understood from the perspective of a theory of lineage that equates the survival of a line with God's blessing.

As for the Great Picture, at first sight it appears to be a formal portrait commemorating Clifford's immediate family and her place 
alongside them. ${ }^{63}$ On closer inspection, however, it becomes a narrative painting, using words to make the images chronicle a series of now-familiar events. She had two versions made, one for each daughter. The Appleby Castle version survives and hangs at Abbot Hall Art Gallery in Kendal, Cumbria. The central panel, framed by thirty-seven tiny escutcheons representing six centuries of the Vipont and Clifford line, depicts her mother, father, and two brothers. The left-hand wing shows Clifford at fifteen, the year that she lost her inheritance, while on the right she is depicted as the Countess of Pembroke, having reclaimed her lands in 1643. We glean this from the copious textual insets that explicate the figures, all of which can be clearly read from close up. In the central panel, Anne's elder brother Francis unflinchingly holds a scroll that tells of his own birth and death followed by those of his brother; the scroll then reveals that all the framed portraits are copied from pictures executed about the beginning of June 1589 in Lord Phillip Wharton's house in Channel Row in Westminster where the "worthy Countess conceyued with Childe the first of May Anno Dm 1589: with hir onely daughter the Lady Ann Clifford, who was borne the 30th of Ianuary following in Skipton Castle in Crauen in Yorkshire,-Shee afterwards being the only Child of hir Parents and is now Countess of Pembrooke. Psa: 139."64

The curiously specific temporal and geographical information on the scroll is identical to the opening of "The Life of Me," and serves to confirm Anne Clifford's legitimacy as George Clifford's heir. ${ }^{65}$ But it is the use of Psalm 139 that gives Clifford's biography particular force, suggesting that her birth and survival, the eventual downfall of her rivals, and her reappropriation of her ancestral lands are all part of a marvelous divine plan. Psalm 139 was a celebration of God's omniscience and a proof text for the doctrine of predestination. Verses 12-5 read, "For my reins are thine: thou hast covered me in my mothers womb. I will give thanks unto thee, for I am fearfully and wonderfully made: marvellous are thy works, and that my soul knoweth right well. My bones are not hid from thee: though I be made secretly, and fashioned beneath in the earth. Thine eyes did see my substance, yet being unperfect: and in thy book were all my members written" (pp. 602-3). But praise for God's protection of the elect modulates into a plea against the wicked in verses 19-22: "Wilt thou not slay the wicked, O God: depart from me ye bloud-thirsty men. For they speak unrighteously against thee: and thine enemies take thy Name in vain. Do not I hate them, O Lord, that hate thee: and am not I grieved with those that rise up against thee? Yea, I 
hate them right sore: even as though they were mine enemies" (p. 603). In the Geneva Bible the running title for Psalm 139 reads "Prayers against the wicked." It was Psalm 139 that was used to substantiate the claim that it was a religious duty to hate the enemies of God and the Church. ${ }^{66}$

The message in Francis's scroll is reinforced pictorially by means of the small book in Lady Margaret's hand-a book of psalms. At the visual center of the triptych, the Psalter rests above the Countess's belly, which we know is soon to swell with the fruit of her womb, its position thereby literalizing "thou hast covered me in my mothers womb" and "in thy book were all my members written." The Psalter makes clear to the viewer that Clifford, like David, is one of the elect. Moreover, Anne has chosen the intrinsically Christian form of the triptych for her narrative, and has positioned herself at the focal point of each panel: in utero at the center of the central panel, deprived of her ancestral lands at fifteen on the left, and having proudly repossessed them on the right. I think we do well to emphasize the implications of this iconography, which retained its devotional associations after the Reformation. ${ }^{67}$ In choosing a triptych, Clifford implies her affinity to another family and a wondrous birth, death, and resurrection.

The Psalter is not the only sacred text depicted in the painting. Both Testaments of the Holy Bible appear in each of the three panels. In the center it lies on a shelf beneath two other books belonging to Lady Margaret. On the left, on the uppermost shelf, stands a folio Bible almost out of reach of the youthful Clifford, whereas on the right a quarto Bible lies on a table under the Countess of Pembroke's right hand. ${ }^{68}$ This Bible confers authority on a scroll that emanates from beneath it, inscribed with an account of the restoration of Clifford's lands; the bottom section of the scroll is left blank, ready to receive her daughters' vital dates. In addition to sacred history, the painting depicts secular and fictional histories. On the right we see European histories among the books jumbled on shelves high above her older head; on the left her revered tutor Samuel Daniel's Chronicles is given shelf room but William Camden's Britannia lies on the floor. Miguel de Cervantes' masterpiece also lies on the ground and is tellingly titled "The Feigned History of Don Quixote." For Clifford, the Holy Bible is the foundation of all knowledge, her only truth, and her right.

Here Holy Writ effectively becomes Clifford's book of law. Significantly, we find scripture being put to similar uses in parliamentary debates during James's reign. ${ }^{69}$ In 1610, just five 
years after Clifford and her mother had begun their legal contest, Nicholas Fuller gave a speech in the House of Commons defending the subjects' right to refuse impositions-the extra-parliamentary import and export taxes levied by the king. Fuller sets out to "prove that the laws of England are the most high inheritance of the land, whereby both king and subjects are directed and guided" and "that by the laws of England the subjects have such property in their lands and goods as that without their consent the king can take no part thereof from them lawfully by any kind of imposition or otherwise without act of Parliament." ${ }^{70}$ Moreover, Fuller insists that "our common laws are the more to be regarded because that they have their foundation as well from the laws of God as from approved reason." ${ }^{1}$ In 1646, as Clifford ruthlessly prepared to repossess as much of her ancestral land as possible, she is reported once again to have repudiated James's award of 1617 and to have claimed "her whole inheritance as rightful heir to her father, both by the laws of God and of the kingdom."72

\section{PROMISED LAND}

In 1649 Clifford left London to claim "the Landes of myne Inheritance" and would remain in the north until her death in 1676 ("Kendal Diary," pp. 114, 126, and 142). From 1650 to 1675 she had members of her household write up summaries at the end of each year, all with a marked consistency of perspective. She documents with obsessive detail each of her numerous restoration projects, her progresses from castle to castle, the length of each stay, and each and every visit of her two daughters, numerous grandchildren, and great-grandchildren. Having recorded the struggle to reclaim her lands in earlier writings, it is here that she documents her final repossession of them and her life marked by "Blessings" (pp. 113, 117, 120, and 128). Biblical references abound, especially in the early and late summaries. Once again, we find chains of references collated from the Old Testament, and once again the Book of Psalms predominates. But now Clifford chooses psalms praising God's wondrous works and his abundant goodness to "mee and mine" (pp. 117 and 120). Here she is using the Bible for different ends than in her earlier writings. Her project is less justificatory; she is not using the Psalmist to authorize her actions and emotions so much as calmly to compare her experiences with those of the Psalmist and assert the truth of his sayings. 
After an extended stay at Skipton Castle in 1650-51, she notes, "this was the first time that I lay for a twelve monthe together in anie of my owne Howses, and there I found by experience and Retyred Life that saying to be true: Eccles. 7.13. Pss. 104.13, 24; 16.6" (pp. 112-3). "[T]hat saying" refers to three separate biblical passages but she clearly understands them to be interchangeable. Psalm 16:6 was a particular favorite and she would quote it in full as "The Lott is fallen unto mee in a pleasant place. I have a fair Heritage" (p. 116).$^{73}$ Shortly afterward, she writes, "And in this Countrey Life of mine I find also that saying of the Psalmist true: 'The Earth is full of the Goodness of the Lord.' Pss. $33.5 ; 104.24 ; 119.64$ " (p. 117). She will say the very same thing in 1652 and use the same biblical chain. ${ }^{74}$

In fact, certain single references and chains do get repeated in the summaries, almost as shorthand for particular emotions. For instance, the death of Herbert, her second husband, recorded in 1650, and that of Queen Henrietta Maria in 1669 both elicit Job 7:1 (pp. 111 and 204). Joy at seeing her younger daughter Isabella and her husband and their son in the north for the first time, in 1654, prompts Clifford to apply Genesis 48:11 to herself: "And Israél said vnto Ioseph, I had not thoght to haue sene thy face; yet lo, God hathe shewed me also thy sede" (p. 126). The same reference is elicited in 1669 when her granddaughter Margaret Coventry and her two children visit Appleby, marking her first sighting of her great-grandchildren in the north (p. 203). Indeed, gratitude for God's providence in giving her grandchildren and great-grandchildren to people her land is registered in "Jer. 29.6; 30.19. Ps. 116. 12, 13, 14," a chain she will deploy three separate times in 1669 and 1670 (pp. 204, 210, and 212). Jeremiah 29:6 reads, "Take you wiues, and beget sonnes, and daughters, and take wiues for your sonnes, and giue your daughters to housbands, that they may beare sonnes \& daughters, that ye may be increased there, and not diminished"; Jeremiah 30:19 reads, "And out of them shal procede thanksgiuing, and the voyce of them that are ioyous, and I wil multiplie them, and thei shal not be fewe: I wil also glorifie them, and they shal not be diminished"; and Psalm 116:12-4 reads, "I will receive the cup of salvation: and call upon the Name of the Lord. I will pay my vows now in the presence of all his people: right dear in the sight of the Lord is the death of his saints. Behold, O Lord, how that I am thy servant: I am thy servant, and the son of thine handmaid, thou has broken my bonds in sunder" (p. 580). Critics have compared "The Life of Me" and the summaries of 1650-75 with the Knole diaries of 
1603-19, and found the former texts lacking in personal detail. But the summaries are found at the end of the third of the Great Books of Record and it is their inclusion here that best alerts us to their purpose. They are not a private account of the latter years of a seventeenth-century aristocratic woman, but rather chronicles of Clifford's divinely ordained role in restoring and cherishing the lands of her inheritance, written not only for her immediate family and their offspring but also for posterity. ${ }^{75}$

\section{CONCLUSION}

This article has discussed both the status of Anne Clifford's Bible relative to other books in her virtual libraries and the nature of her Biblicism in her writings and visual memorials. I argued that the Bible was fundamental to Clifford's library and the source of all true knowledge of God and the world. It was the Word that underpinned her conviction that her lands had returned to her according to God's providential plan, and empowered her to resist a series of male figures, not least James I. Yet Clifford's Biblicism was marked by restraint. It was not the Biblicism of Mary Rich, Mildmay, or the Civil War prophetesses. It is not the ecstasy of spiritual inspiration; she is never carried away by passions when encountering the Word. ${ }^{76}$ Instead she uses biblical references restrainedly and systematically as shorthand for particular emotions, thereby personalizing her history without ever exceeding the bounds of decorum. Such emotional restraint is very much in keeping with Clifford's Stoic disposition, a trait shared by her mother, fostered by her tutor Daniel, and corroborated by the tomes of Stoic philosophy included in the Great Picture-works by Epictetus, Boethius, Seneca, and Pierre Charron. ${ }^{77}$ It is very much in keeping with her moderate, "Jacobethan" sensibilities.

\section{NOTES}

\footnotetext{
${ }^{1}$ For Anne Clifford's life and writing, see Barbara Kiefer Lewalski's pioneering Writing Women in Jacobean England (Cambridge MA: Harvard Univ. Press, 1993), pp. 125-51; Katherine Acheson, introduction to The Memoir of 1603 and The Diary of 1616-1619, by Anne Clifford, ed. Acheson (Peterborough ON: Broadview Editions, 2007), pp. 9-36; and Richard T. Spence, Lady Anne Clifford: Countess of Pembroke, Dorset, and Montgomery (1590-1676) (Stroud UK: Sutton Publishing, 1997).

${ }^{2}$ For an account of the ways in which Anne Clifford's later writings and the inscriptions on her buildings "require each other to complete their meanings," see Anne M. Myers, Literature and Architecture in Early Modern
} 
England (Baltimore: Johns Hopkins Univ. Press, 2013), pp. 132-59, 133. Hereafter, unless otherwise noted all instances of "Clifford" refer to Anne Clifford. All others with the surname Clifford will be identified by both their first and last names throughout.

${ }^{3}$ For a list of the titles and arrangement of the books in the triptych, see Spence, pp. 190-1. Graham Parry discusses the content of her virtual library, especially her predilection for ancient and modern Stoic philosophy and moderate Calvinism, in "The Great Picture of Lady Anne Clifford," in Art and Patronage in the Caroline Courts: Essays in Honour of Sir Oliver Millar, ed. David Howarth (Cambridge: Cambridge Univ. Press, 1993), pp. 202-19.

${ }^{4}$ For discussions of Clifford's use of books in general, see Lewalski, pp. 137 and 150; Mary Ellen Lamb, "The Agency of the Split Subject: Lady Anne Clifford and the Uses of Reading," ELR 22, 3 (Autumn 1992): 347-68; and Heidi Brayman Hackel, Reading Material in Early Modern England: Print, Gender, and Literacy (Cambridge: Cambridge Univ. Press, 2005), pp. 221-40. More recently, Julie Crawford has focused on the religious texts Clifford read, including Augustine's City of God, Robert Persons and Edmund Bunny's Resolutions, Psalms, and Christian Stoic texts associated with her mother. Crawford argues that she deployed these texts for predominantly political ends as "a record of opposition to the king and alignment with a set of reading and interpretative practices associated ... with aristocratic privilege and godly resistance" ("Lady Anne Clifford and the Uses of Christian Warfare," in English Women, Religion, and Textual Production, 1500-1625, ed. Micheline White [Aldershot UK: Ashgate, 2011], pp. 101-23, 103).

${ }^{5}$ On the tendency to categorize Clifford's writing as secular, see Lewalski, pp. 141 and 147; Ramona Wray, "Autobiography," in The Cambridge Companion to Early Modern Women's Writing, ed. Laura Lunger Knoppers (Cambridge: Cambridge Univ. Press, 2009), pp. 194-207; and Crawford, "Uses of Christian Warfare," p. 103. On the slowness of scholars to engage with actual early modern biblical reading practices, see William H. Sherman, Used Books: Marking Readers in Renaissance England (Philadelphia: Univ. of Pennsylvania Press, 2008), p. 72. Such wariness can be detected in editorial practice too, with biblical references either assumed to be self-explanatory or wholly omitted. For example, D. J. H. Clifford decides "in the interest of brevity" to omit many of the Old Testament references that follow almost every entry of Clifford's "day book" (1676) (Clifford, The Diaries of Lady Anne Clifford, ed. D. J. H. Clifford [Stroud UK: Sutton, 2003], p. 238).

${ }^{6}$ This paper has benefited from my discussions with Richard Cust, Indira Ghose, Ian Green, Bruce Lawder, Martin Mühlheim, Clare Tilbury, Allen Reddick, and Helen Wilcox.

${ }^{7}$ See Kate Narveson, Bible Readers and Lay Writers in Early Modern England: Gender and Self-Definition in an Emergent Writing Culture (New York: Ashgate, 2012); and Femke Molekamp, Women and the Bible in Early Modern England: Religious Reading and Writing (Oxford: Oxford Univ. Press, 2013).

${ }^{8}$ For a subtle account of providentialism, predestination, and its rival ideologies, see Alexandra Walsham, Providence in Early Modern England (Oxford: Oxford Univ. Press, 1999), pp. 1-64; and Blair Worden, "Providence and Politics in Cromwellian England," Past and Present 109 (November 1985): 55-99, 66. 
${ }^{9}$ See Edward Rainbowe, A Sermon Preached at the Funeral of the Right Honorable Anne, Countess of Pembroke, Dorset and Montgomery Who Died March 22, 1675/6, and was Interred April the 14th Following at Appleby in Westmorland: With Some Remarks on the Life of that Eminent Lady (London: R. Royston and H. Broom, 1677), p. 59; EEBO Wing R142; and Spence, p. 221.

${ }^{10}$ For the terms "Jacobethan" and "moderate" as applied convincingly to Clifford's brother-in-law, Edward Sackville, see David L. Smith, "Catholic, Anglican, or Puritan?: Edward Sackville, Fourth Earl of Dorset and the Ambiguities of Religion in Early Stuart England," Transactions of the Royal Historical Society 2 (December 1992): 105-24.

${ }^{11}$ See Spence, pp. 14, 62, 65, 95, 97, and 225-6. Queen Anne sided with Clifford over the inheritance battle (See Clifford, "The Diary of 1616-1619," in The Memoir of 1603 and The Diary of 1616-1619, pp. 61-189, 110-1). All subsequent references to "The Diary of 1616-1619" are from this edition and will be cited parenthetically in the text by page number. For a discussion of the Court, Clifford's alliances, and rival sites of power, see Crawford, "The Case of Lady Anne Clifford: Or, Did Women Have a Mixed Monarchy?" PMLA 121, 5 (October 2006): 1682-9.

${ }^{12}$ See Spence, pp. 105-8 and 138.

${ }^{13}$ For Clifford's religious profile and devotional habits, see Rainbowe, pp. 57-63; and Spence, pp. 17, 221, and 225-7.

${ }^{14}$ Spence, pp. 241-3.

${ }^{15}$ See Clifford, "Appendix D: From Anne Clifford, 'A Summary of the Records and a True Memorial of the Life of Me the Lady Anne Clifford' (1652)," in The Memoir of 1603 and The Diary of 1616-1619, pp. 217-32; and Clifford, "The Kendal Diary, 1650-1675," in The Diaries of Lady Anne Clifford, pp. 109-235. All subsequent references to "The Life of Me" and "The Kendal Diary" are to these editions and will be cited in the text and notes parenthetically by page number.

${ }^{16}$ Men and women across confessional divides put psalms to similar uses. See Margaret P. Hannay “'So May I With the Psalmist Truly Say': Early Modern Englishwomen's Psalm Discourse," in Write or Be Written: Early Modern Women Poets and Cultural Constraints, ed. Barbara Smith and Ursula Appelt (Aldershot UK: Ashgate, 2001), pp. 104-34, 105-6; Hannibal Hamlin, Psalm Culture and Early Modern English Literature (Cambridge: Cambridge Univ. Press, 2004), pp. 15 and 240-52; and Molekamp, pp. 71-4 and 219-20.

${ }^{17}$ Brian Cummings, ed., The Book of Common Prayer: The Texts of 1549, 1559, and 1662 (Oxford: Oxford Univ. Press, 2011), p. 498. Psalms will be cited from the Book of Common Prayer (hereafter BCP) throughout the paper, as Clifford's own unattributed quotations most closely resemble the prose translation of the psalms hallowed by the Book of Common Prayer, namely that of The Great Bible of 1539, itself a slightly modified and renumbered version of Myles Coverdale's translation of 1535 (hereafter TCB). All citations of the Book of Common Prayer are from Cummings's edition and will be cited parenthetically in the text by page number. All other books will be cited from the Geneva Bible of 1560 (hereafter Gen.).

${ }^{18}$ See Alec Ryrie, "The Psalms and Confrontation in English and Scottish Protestantism," ARG 101, 1 (October 2010): 114-37, 127-37.

${ }^{19}$ See Worden, "Providence and Politics," pp. 75-7; and Walsham, pp. 16-7 and 225-80. 
${ }^{20}$ Lady Grace Mildmay, "Autobiography," chap. 2 in With Faith and Physic: The Life of a Tudor Gentlewoman, Lady Grace Mildmay, 1552-1620, by Linda Pollock (London: Collins and Brown, 1993), pp. 23-47, 36 and 38.

${ }^{21}$ See Felicity Heal and Clive Holmes, The Gentry in England and Wales, 1500-1700 (Stanford: Stanford Univ. Press, 1994), pp. 20-47.

${ }^{22}$ Sir Edward Dering, qtd. in Heal and Holmes, p. 32.

${ }^{23}$ See Cust, "The Material Culture of Lineage in Late-Tudor and EarlyStuart England," in The Routledge Handbook of Material Culture in Early Modern Europe, ed. Catherine Richardson, Tara Hamling, and David Gaimster (London: Routledge, 2017).

${ }^{24}$ Thanet fireplace inscription, qtd. in Spence, p. 241.

${ }^{25}$ Spence, pp. 239-42.

${ }^{26}$ Clifford would continue to keep a reading diary. See Stephen Orgel, "Marginal Maternity: Reading Lady Anne Clifford's A Mirror for Magistrates," in Printing and Parenting in Early Modern England, ed. Douglas A. Brooks (Aldershot UK: Ashgate, 2005) pp. 267-89; and Orgel, The Reader in the Book: A Study of Spaces and Traces (Oxford: Oxford Univ. Press, 2015), pp. 138-57.

${ }^{27}$ See Brayman Hackel, p. 206.

${ }^{28}$ Acheson notes that "the History of the Netherlands" was "[i]dentified by [Mihiko] Suzuki as A Tragical History of the Troubles and Civil Wars of the Low Countries, 1559-1581, translated by Thomas Stock and published in 1583" (Clifford, "The Diary of 1616-1619," p. 99n85).

${ }^{29}$ The "King's book" is James I's A Meditation upon the Lord's Prayer (1619). Spence has identified "in the praise of a Solitary Life" as a manuscript by John Harrington (p. 71).

${ }^{30}$ For details of the range of formats, see Green, Print and Protestantism in Early Modern England (Oxford: Oxford Univ. Press, 2000), pp. 56-62.

${ }^{31}$ David Cressy, "Books as Totems in Seventeenth-Century England and New England,” JLH 21, 1 (Winter 1986): 92-106, 97.

${ }^{32}$ A "standing" is a "hunter's station or stand from which to shoot game" (OED, 2d edn., n., "standing," 4c).

${ }^{33}$ Clifford's unacknowledged quotation most closely resembles the version in the Book of Common Prayer. Compare "like an owl that is in the desert" (BCP); "like an Oule in a broken wall" (TCB, Ps. 101); "like an owl of the deserts" (Gen.); and "like an owl of the desert" (AV).

${ }^{34}$ Susan Wiseman reads Clifford's diaries as public, political documents in "Knowing Her Place: Anne Clifford and the Politics of Retreat," in Textures of Renaissance Knowledge, ed. Philippa Berry and Margaret Tudeau-Clayton (Manchester: Manchester Univ. Press, 2003), pp. 199-221, 199-206. For a similar reading of this particular episode, see Crawford, "Uses of Christian Warfare," pp. 108-9.

${ }^{35}$ See Patrick Collinson, "The Coherence of the Text: How It Hangeth Together: The Bible in Reformation England," in The Bible, the Reformation, and the Church: Essays in Honour of James Atkinson, ed. W. P. Stephens (Sheffield UK: Sheffield Academic Press, 1995), pp. 84-108, 89.

${ }^{36}$ John Downame, A Guide to Godlynesse or a Treatise of a Christian Life Shewing the Duties Wherein It Consisteth, the Helpes Inabling and the Reasons Parswading unto It ye Impediments Hindering ye Practise of It, and the Best Meanes to Remoue Them Whereunto Are Added Diuers Prayers and 
a Treatise of Carnall Securitie (London: Felix Kingstone, 1622); EEBO STC (2d edn.) 7143.

${ }^{37}$ Downame, p. 635.

${ }^{38}$ Ibid.

${ }^{39}$ Downame, p. 648.

${ }^{40}$ Ibid.

${ }^{41}$ Ibid. For an account of the range of advice literature available in print, see Green, pp. 144-8.

${ }^{42}$ One example of such a prescription is T. Grashop's schema, which often prefaced black-letter quarto editions of the Geneva Bible (qtd. in Sherman, p. 73).

${ }^{43}$ For a transcription of the wording on the spines of the books in the triptych, see G. C. Williamson, Lady Anne Clifford, Countess of Dorset, Pembroke \& Montgomery. 1590-1676. Her Life, Letters, and Work. (Kendal UK: Titus Wilson and Son, 1922), pp. 498-500.

${ }^{44}$ See Richard A. McCabe, "Hall, Joseph (1574-1656)" in Oxford Dictionary of National Biography (Oxford: Oxford Univ. Press, 2004), doi:10.1093/ ref:odnb/11976.

${ }^{45}$ See Arnold Hunt, "Austin, William (1587-1634)," in Oxford Dictionary of National Biography, doi:10.1093/ref:odnb/917; and Parry, Glory, Laud and Honour: The Arts of the Anglican Counter-Reformation (Woodbridge UK: Boydell Press, 2008), pp. 121-7.

${ }^{46}$ See the appointed order and calendar in the BCP, pp. 217-38.

${ }^{47}$ See Rainbowe, p. 59; and Spence, p. 221.

${ }^{48}$ See Clifford, The Diaries of Lady Anne Clifford, pp. 240, 242, and 244.

${ }^{49}$ See Peter E. McCullough, Sermons at Court: Politics and Religion in Elizabethan and Jacobean Preaching (Cambridge: Cambridge Univ. Press, 1998).

${ }^{50}$ McCullough, "King, John (d. 1621)," in Oxford Dictionary of National Biography, doi:10.1093/ref:odnb/15568.

${ }^{51}$ The household accounts for 1675 record Clifford's payment "for new binding an old bible that was my Mother's," qtd. in Crawford, "Uses of Christian Warfare," p. 115n54.

${ }^{52}$ The Geneva Bible, produced in small and affordable formats and equipped with multiple reading aids, remained popular with a broad spectrum of readers far into the seventeenth century. See Hamlin and Norman W. Jones, eds., The King James Bible after 400 Years: Literary, Linguistic, and Cultural Influences (Cambridge: Cambridge Univ. Press, 2010), pp. 6-8; and Molekamp, pp. 14 and 19-50.

${ }^{53}$ George Abbot, chaplain to Richard Sackville's grandfather at Oxford, was part of the Second Oxford Company of translators, responsible for the New Testament. Dr. John Layfield, one of the executors of Margaret Clifford's will, was part of the First Westminster Company, responsible for Genesis to 2 Kings.

${ }^{54}$ See Cummings, "Note on the Texts," in BCP, pp. liii-lxiv, lvi.

${ }^{55}$ Compare Isaiah 40:6: "The same voyce spake: Now crie. And I sayde: what shal I crie? Then spake it: that, all flesh is grasse, and that all the bewtie therof, is as the floure of the felde" (TCB); "A voyce said, Crye. And he said, What shal I crye? All flesh is grass, and all the grace thereof is as ye floure of the field" (Gen.); and "The voice said, Cry. And he said, What shall I cry? All flesh is grass, and all the goodliness thereof is as the flower of the field" (AV). 
${ }^{56}$ Compare I Chronicles 4:22: "These also are wordes of olde" (TCB); "These also are ancient things" (Gen.); and "And these are ancient things" (AV).

${ }^{57}$ See Spence, pp. 160-80; and Jessica L. Malay, ed., Anne Clifford's Great Books of Record (Manchester: Manchester Univ. Press, 2015).

${ }^{58}$ Narveson, p. 34. See also Narveson, pp. 34-42 and 55-65; and Molekamp, pp. 55-63.

${ }^{59}$ Margaret Clifford to Anne Clifford, 22 September 1615, Cumbria Records Office, Kendal, WD/Hoth/Box 44, qtd. in Lewalski, pp. 134-5, 135.

${ }^{60}$ See Hannay, pp. 117-8.

${ }^{61}$ See Molekamp, pp. 67-74.

${ }^{62}$ See Molekamp, pp. 219-20.

${ }^{63}$ The Great Picture has long been attributed to the copyist Jan van Belcamp, but more recent scholarship has suggested the possible involvement of Sir Peter Lely. See Alice T. Friedman, "Constructing an Identity in Prose, Plaster, and Paint: Lady Anne Clifford as Writer and Patron of the Arts," in Albion's Classicism: The Visual Arts in Britain, 1550-1660, ed. Lucy Gent (New Haven: Yale Univ. Press, 1995), pp. 359-76, 363.

${ }^{64}$ The transcription of the wording on Francis's scroll is my own.

${ }^{65}$ Much of the wording in the tiny biographies below each of the escutcheons framing the central panel of the Great Picture will be echoed in Clifford's biographies of her ancestors in the Great Books of Record, proving the extent of her involvement in the design of the painting.

${ }^{66}$ See Christopher Hill, The English Bible and the Seventeenth-Century Revolution (London: Penguin, 1993), p. 384.

${ }^{67}$ For a discussion of the use of the triptych and its religious implications in Tudor dynastic portraiture and in post-Reformation ecclesiastical and domestic settings, see Friedman, p. 363; and Hamling, Decorating the "Godly" Household: Religious Art in Post-Reformation Britain (New Haven: Yale Univ. Press, 2010), p. 225. Spence speculates that Clifford may have seen examples in the Arundel and Royal collections, and perhaps at Wilton House (p. 182).

${ }^{68}$ The Bible actually lies beneath Pierre Charron's Book of Wisdom (1601), a work of neo-Stoic philosophy. For more information on Charron's Book of Wisdom, see Crawford, "Uses of Christian Warfare," pp. 121-2.

${ }^{69}$ See Johann Sommerville, Politics and Ideology in England, 1603-1640 (London: Longman, 1986), pp. 145-73; Sommerville, "Ideology, Property, and the Constitution," in Conflict in Early Stuart England: Studies in Religion and Politics, 1603-1642, ed. Cust and Anne Hughes (1989; rprt. London and New York: Routledge, 2014), pp. 47-71; and Worden, The English Civil Wars, 1640-1660 (London: Orion, 2009), pp. 7 and 14-20.

${ }^{70}$ Nicholas Fuller, "June 23, 1610," in House of Commons, vol. 2 of Proceedings in Parliament 1610, ed. Elizabeth Read Foster, 2 vols. (New Haven: Yale Univ. Press, 1966), pp. 151-65, 152.

${ }^{71}$ Ibid.

${ }^{72}$ Spence, p. 108.

${ }^{73}$ Once again this quotation is an amalgam of the phrasings in Geneva and TCB, suggesting that she is quoting from memory.

74 "And in this Country life of myne, I mynde that saying of the psalmist true-'The Earth is full of the goodnesse of the Lorde.' Pss. 33.5; 104.24; 119.64" (“Kendal Diary," p. 120). 
${ }^{75}$ Aaron Kunin sees Clifford's diaries and annual summaries as collaborative and "self-consciously historical" documents ("From the Desk of Anne Clifford," ELH 71, 3 [Fall 2004]: 587-608, 591). Paul Salzman argues that while Clifford was writing for "herself," she was simultaneously writing for a much wider future audience ("Anne Clifford: Writing for Oneself, Writing for Others," ParergonJ 27, 1 [January 2010]: 125-41, 137).

${ }^{76}$ For affective piety and the tension between Augustinian and neo-Stoic attitudes to emotion, see Molekamp, pp. 119-50.

${ }^{77}$ The Stoical bias of her virtual library is discussed in Parry, "The Great Picture," pp. 208 and 212-5; and Crawford, "Uses of Christian Warfare," pp. 120-2. 